\title{
Assessment of Nutritional Status: A Case of Tribal Children in Assam, Northeast India
}

\author{
Singh $\mathrm{J}^{1}$, Mondal $\mathbf{N}^{2}$ \\ ${ }^{1}$ Dr, Jaswant Singh Ph.D, Department of Anthropology, \\ Dibru College, Dibrugarh-786003, Assam, India, \\ ${ }^{2}$ Mr. Nitish Mondal, M.Sc. Department of Anthropology, \\ Assam University Diphu Campus, Diphu, Karbi \\ Anglong-782 460, Assam, India.
}

\section{Introduction}

Undernutrition is a serious public health problem among children in the developing countries ${ }^{1}$. Child undernutrition is one of the measures of health status that the World Health Organization (WHO) recommends for equity in health ${ }^{2}$. Conversely, undernutrition has been estimated to be an underlying cause for around half of all child deaths worldwide ${ }^{3}$. Recent comparative risk assessment study on undernutrition is estimated to be the largest contributor to the global burden of disease $e^{3,4}$. It has been estimated this approximately $70.00 \%$ of the world's undernourished children live in Asia, giving that region the highest concentration of worldwide childhood undernutrition $^{5}$. Moreover, India shows the highest occurrence of childhood undernutrition in the world ${ }^{6}$ and it has been estimated that more than half of Indian children are undernourished ${ }^{7}$. A recent large scale survey in India reported that $42.30 \%$ and $58.80 \%$ of the preschool (less than 5 years) children were found to be underweight and stunted respectively ${ }^{8}$. Given recent statistics, undernutrition continues to be the major cause of ill-health and premature mortality and morbidity of the children in developing countries including India ${ }^{1,3,7,9}$. Recent studies in India have primarily focused on the problem of undernutrition, particularly among women and children ${ }^{10}$.

The prevalence of child undernutrition is generally assessed by conventional anthropometric indices of stunting (height-for-age), underweight (weight-for-age) and wasting (weight-for-height) following recommended international standards $s^{1,11,12}$, although conventional anthropometric indices are unable to provide the actual magnitude of undernutrition due to overlapping

\footnotetext{
Address for correspondence

Dr. Jaswant Singh

Assistant Professor

Department of Anthropology, Dibru College,

Dibrugarh, P.O: Boiragimoth, Assam - 786003, INDIA

E-mail: jaswantsingh79@yahoo.co.in
}

\begin{abstract}
Introduction: Thinness is a major underlying problem among children and adolescents in the developing countries including India. The present study was carried out to determine the prevalence of nutritional status among the Sonowal Kachari children aged 6-18 years of Dibrugarh district of Assam, Northeast India. Materials and Methods: The cross-sectional data on height and weight measurements were collected among 1343 (670 boys, 673 girls) children belonging to Sonowal Kachari tribal ethnic group using multi-stage stratified sampling procedure. The Body Mass Index $\left\{\right.$ BMl=weight $(\mathrm{kg}) /$ height $\left.^{2}\left(\mathrm{~m}^{2}\right)\right\}$ was calculated. The new international cut-off points of Cole et al. were used to classify the magnitude of thinness. Results: The overall mean BMI was found to be significantly higher among girls than the boys $(p<0.01)$. The overall prevalence of thinness was observed to be $25.99 \%$ ( $28.08 \%$ boys, $23.92 \%$ girls) $(p>0.05)$. The prevalence of thinness was generally higher in the early age (6-11 years), but thereafter decreased with age in both sexes. Conclusion: The results of the present study clearly indicate that the nutritional status of these children is unsatisfactory. Nutritional intervention in terms of a comprehensive supplementary balanced diet and micronutrient rich or protective foods should be introduced to ameliorate the nutritional status.
\end{abstract}

Key words: Thinness; BMI; Sonowal Kachari; Northeast India; undernutrition

in nature ${ }^{1,13}$. The body mass index (BMI) as measured by weight in kilogram $(\mathrm{kg})$ divided by height in meter (m) squared, is an inexpensive and non-invasive anthropometric measure that has been extensively utilized to assess the chronic energy deficiency (CED; $\mathrm{BMl}<18.50 \mathrm{~kg} / \mathrm{m} 2$ ) and thinness (low BMl-for-age) among adults and adolescents respectively ${ }^{11}$. Very recently, international age and sex specific reference

\section{How to cite this article ?}

Singh J, Mondal N. Assessment of Nutritional Status: A Case of Tribal Children in Assam, Northeast India. J Nepal Paediatr Soc 2013;33(1):1-7. 
and cut-offs have been proposed to evaluate the prevalence of overweight and obesity ${ }^{14}$ and thinness ${ }^{15}$ among children in the age range of 2 years to 18 years. The information on the thinness prevalence in children of developing countries like India is needed to be generated from national as well as international comparisons. In India, given its large population size and widespread poverty, a majority of individuals are undernourished and underprivileged ${ }^{1,6,7,12,13}$. Moreover, the recent study has already advocated that undernutrition is better assessed as thinness rather than wasting among the children ${ }^{15}$. Therefore, the present study has been undertaken to assess the prevalence of low BMI-forage among children aged 6-18 years residing in an economically and socially backward tribal blocks of the state of Assam, Northeast India by using these newly proposed age and sex specific cut-offs ${ }^{15}$.

\section{Materials and Methods}

The present community based, cross sectional study was carried out among 1343 (670 boys, 673 girls) tribal Sonowal Kachari children aged 6-18 years of Dibrugarh district (Latitude $27^{0} 42^{\prime} 30^{\prime \prime} \mathrm{N}$, Longitude $\left.95^{\circ} 29^{\prime} 8 " \mathrm{E}\right)$ of Assam, Northeast India, situated 426 $\mathrm{km}$ from Dispur, the state capital of Assam. The community area has an area of $3381 \mathrm{~km}^{2}$ having a total population of $11,85,072(6,13,555$ males; $5,71,517$ females) individuals with total literacy rate of $87.30 \%{ }^{16}$. Currently, the Sonowal Kachari's are mainly engaged as an agriculturist and concentrated mostly in the upper districts of Dibrugarh, Tinsukia, Sibsagar, Jorhat, Golaghat, Sonitpur, Lakhimpur and Dhemaji of Assam ${ }^{17,18}$. The Sonowal Kachari is enlisted as a scheduled tribe in the plains of Assam. Ethnically, they belong to Mongoloid tribal ethnic population and showing affinity with Boro Kachari, Dimasa Kachari and Thengal Kachari. According to the Census 2001, the total population of Sonowal Kachari is 2,35,881 and constitutes $7.10 \%$ of total scheduled tribe's population of Assam ${ }^{16}$. The collection of data was done from July 2006 to January 2008. A total of 20 lower primary and 16 higher secondary schools from 26 villages of Dibrugarh district of Assam were covered using multistage stratified random sampling method. A total of 1485 (743 boys; 642 girls) children belonging to a Sonowal Kachari ethnic group of aged 6 years to 18 were identified and approached. Of these 1485 children, a total of 142 (77 boys; 65 girls) children whose dates of birth were either not available or inappropriate in the school records or were not in the age group of 6-18 years were excluded. The anthropometric measurements were collected in the respective schools. Special care was taken so that each category (age/sex) had a minimum of 50 children. The school records were utilized to ascertain their age which was subsequently verified from their birth and official records. All the children were free from any physical deformity and not suffering from any disease at the time of examination. Any previous histories related to medical and surgical episodes were also taken into consideration during the time of examination. All necessary approvals and consents were obtained from the village level local authorities and school authorities prior to conducting the study. Parents of the children were informed about the objectives of our study before obtaining of the measurements. All the necessary approvals, consents and permissions of the study protocols were taken from the Dibrugarh University. The study was conducted in accordance with the ethical guidelines for human experiments as laid down in the Helsinki Declaration of $2000^{19}$.

\section{Collection of Anthropometric measurement and Assessment of Nutritional status}

The anthropometric measurements of height and weight were recorded from selected children using standard procedures ${ }^{20}$. Height of the children was recorded to the nearest $0.1 \mathrm{~cm}$ with the help of an anthropometric rod with the head held in the Frankfort horizontal plane. The weight of the children wearing minimum clothing and with bare feet was taken using a portable weighing scale to the nearest $100 \mathrm{gm}$. The intra-observer and inter- observer differences were calculated for testing the co-efficient of reliability $(R)$ of the collected anthropometric measurements using the technical error measurement $\left\{T E M=\sqrt{ }\left(\sum D 2 / 2 N\right)\right.$, $D=$ difference between the measurements, $N=$ number of individuals measured\} following the method of Ulijaszek and $\mathrm{Kerr}^{21}$. Very high values of $\mathrm{R}(>0.98)$ were obtained for height and weight for both inter- and intra-observer TEM analysis and these values were found within the cutoff values of 0.95 as suggested by Ulijaszek and Kerr ${ }^{21}$. Hence, the measurements obtained in the present study were considered to be reliable and reproducible. The TEM values were not incorporated for further statistical consideration.

The BMI was calculated following the internationally accepted standard equation ${ }^{11}$ : BMl=Weight $(\mathrm{kg}) / \mathrm{Height}^{2}$ $\left(\mathrm{m}^{2}\right)$. The prevalence thinness was assessed following the international BMI cut-off points proposed by Cole et al. $^{15}$. The BMl values were used to determine the definite grades of thinness (Grade-III: severe, Grade-II: moderate, Grade-l: mild), these above classifications are similar to the different grades of adult chronic energy deficiency (CED) ${ }^{11}$. The CED is the chronic undernutrition is classified as BMI found below 18.50 $\mathrm{kg} / \mathrm{m}^{2}$ among adults ${ }^{11}$. In the present study, a child found below of any thinness grades I, II and III of the age and sex specific cut-off values of the international reference population is classified as mild, moderate and severely thin respectively ${ }^{15}$. 


\section{Statistical Analysis}

The data were statistically analysed using the Statistical Package for Social Science (SPSS, Inc., Chicago, IL; version 15.0). A p-value of less than 0.05 was considered to be statistically significant. The descriptive statistical analysis of the data obtained was depicted in terms of mean and standard deviation (SD). One way analysis of variance (ANOVA) using the Scheffe procedure was done to assess age and sex differences in overall and age-specific weight, height and BMI. The Chi-square analysis was used to assess the sex differences in the prevalence of different grades of thinness. The Least Mean Square (L, M and S) model approach was utilized to convert the measurements for a child of known age- and sex- to evaluate the centile and standard deviation score or Z-score, as proposed by Cole and Green ${ }^{22}$ and Cole et al. ${ }^{23}$. The L, M and S model approach take into the account the degree of skewness (L), central tendency (M; Median) and dispersion or the generalized coefficient of variation (S) for the conversion. This method was used to derive the age- and sexspecific percentile reference curves of BMI. The method summarizes percentiles at each age based on the power of age-specific Box-Cox power transformations used to normalize data. The centile curves $\left(3^{\text {rd }}, 10^{\text {th }}, 25^{\text {th }}, 50^{\text {th }}\right.$, $75^{\text {th }}, 90^{\text {th }}$ and $97^{\text {th }}$ ) were derived as reference data for further evaluation of body composition. The LMS Chart Maker software program (The Institute of Child Health, London) was used to obtain the smooth centile curves that fitted smooth centile curves to the reference data.

\section{Results}

The age and sex specific subject distribution, mean $\pm S D$ of weight, height and BMI and prevalence of different grades of thinness among the studied Sonowal Kachari children are depicted in Table 1. The boys are found to be taller $(p<0.01)$ and heavier $(p>0.05)$ than girls in all age groups. The age specific mean values of weight, height and BMI values were observed to be progressively increased with age among both boys and girls. The overall mean BMI among girls (17.22 \pm 2.93 $\mathrm{kg} / \mathrm{m}^{2}$ ) was found significantly higher than the boys $\left(16.62 \pm 2.34 \mathrm{~kg} / \mathrm{m}^{2}\right)(p<0.01)$. The age and sex specific mean BMI values were found to be higher among girls when compared to boys in most ages, with exception observed in 6 years, 8 years, 9 years and 10 years. The age specific mean BMI was ranged from $14.21 \pm 0.99 \mathrm{~kg} /$ $\mathrm{m}^{2}$ to $19.71 \pm 1.21 \mathrm{~kg} / \mathrm{m}^{2}$ (in boys) and $13.79 \pm 0.96 \mathrm{~kg} /$ $\mathrm{m}^{2}$ to $20.69 \pm 1.04 \mathrm{~kg} / \mathrm{m}^{2}$ (in girls) among children aged 6 years to 18 years respectively. Using ANOVA, there were statistically significant sex differences observed in height ( $F$ value $=8$. 25; d.f. 1, 1342; $p<0.01)$ and BMI ( $F$ value $=17$. 47; d.f. 1, 1342; $p<0.01)$ except in height $(F$ value $=0.42 ;$ d.f. 1,$1342 ; p>0.05)$ between the sexes $(p<0.05)$. Using ANOVA, the differences in anthropometric measurements were also found to be statistically significant $(p<0.01)$ with respect to age and weight $(F$ value $=433.99$, d.f. 12, 669, $p<0.01)$, height $(F$ value $=572$. 15, d.f. 12,669, $p<0.01)$ and $B M I(F$ value =125. 96, d.f. 12, 669, $\mathrm{p}<0.01$ ) among boys and also age and weight ( $F$ value $=460.65$, d.f. 12, 672, $p<0.01$ ), height $(F$ value $=547.92$, d.f. 12, 672, $p<0.01)$ and $B M I$ ( $F$ value $=140.53$, d.f. 12, 672, $p<0.01)$ among girls. The age and sex specific smooth percentile curves $\left(3^{\text {rd }}, 10^{\text {th }}\right.$, $25^{\text {th }}, 50^{\text {th }}, 75^{\text {th }}, 90^{\text {th }}$ and $97^{\text {th }}$ ) for BMI were derived for the further evaluation of nutritional status using $L, M$ and $S$ parameter in the model approach statistical procedures among the Sonowal Kachari boys and girls are depicted separately in Figure 1.

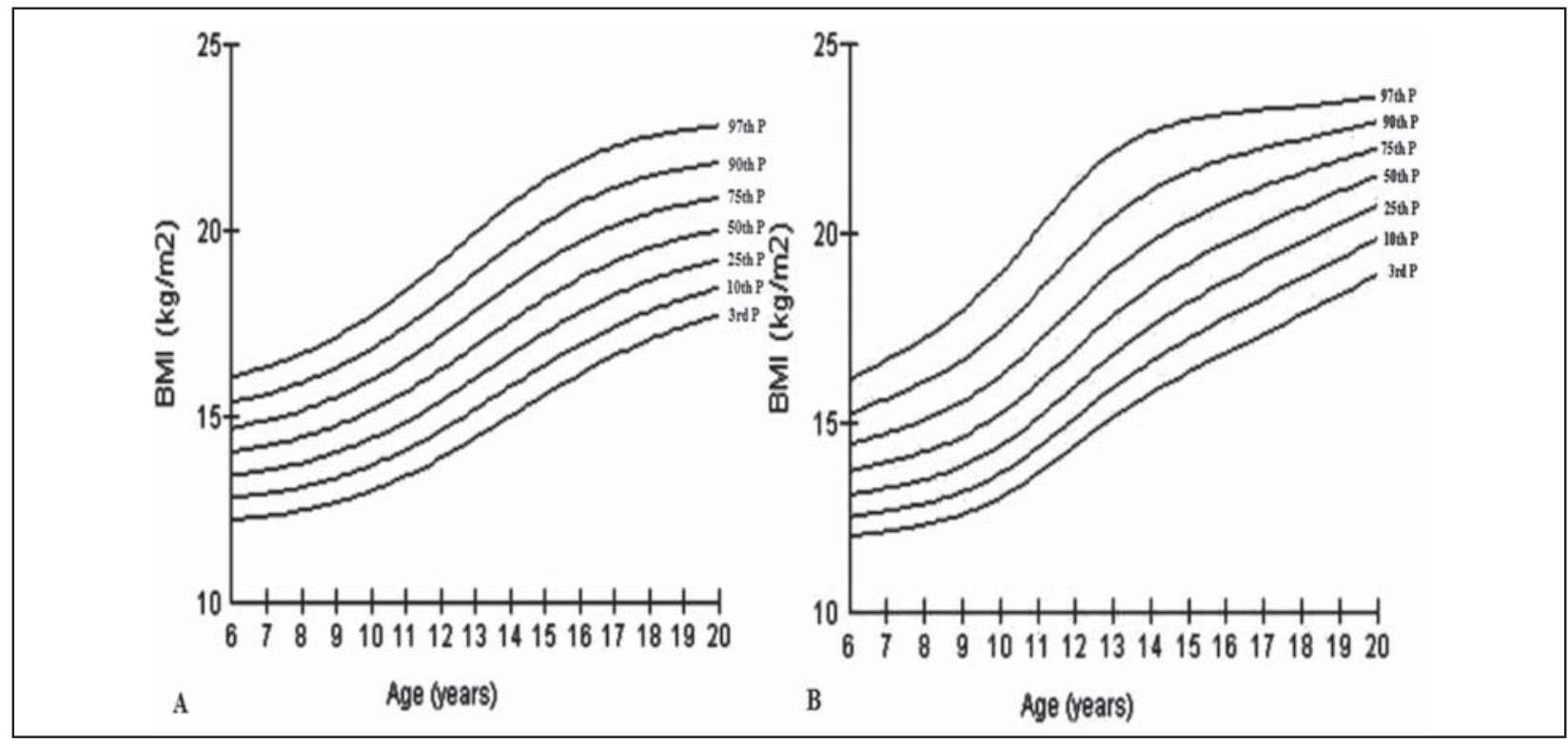

Fig 1: Age and sex specific smooth percentile curves of BMI using L, M and $S$ model approach among the Sonowal Kachari Boys (A) and Girls (B) 


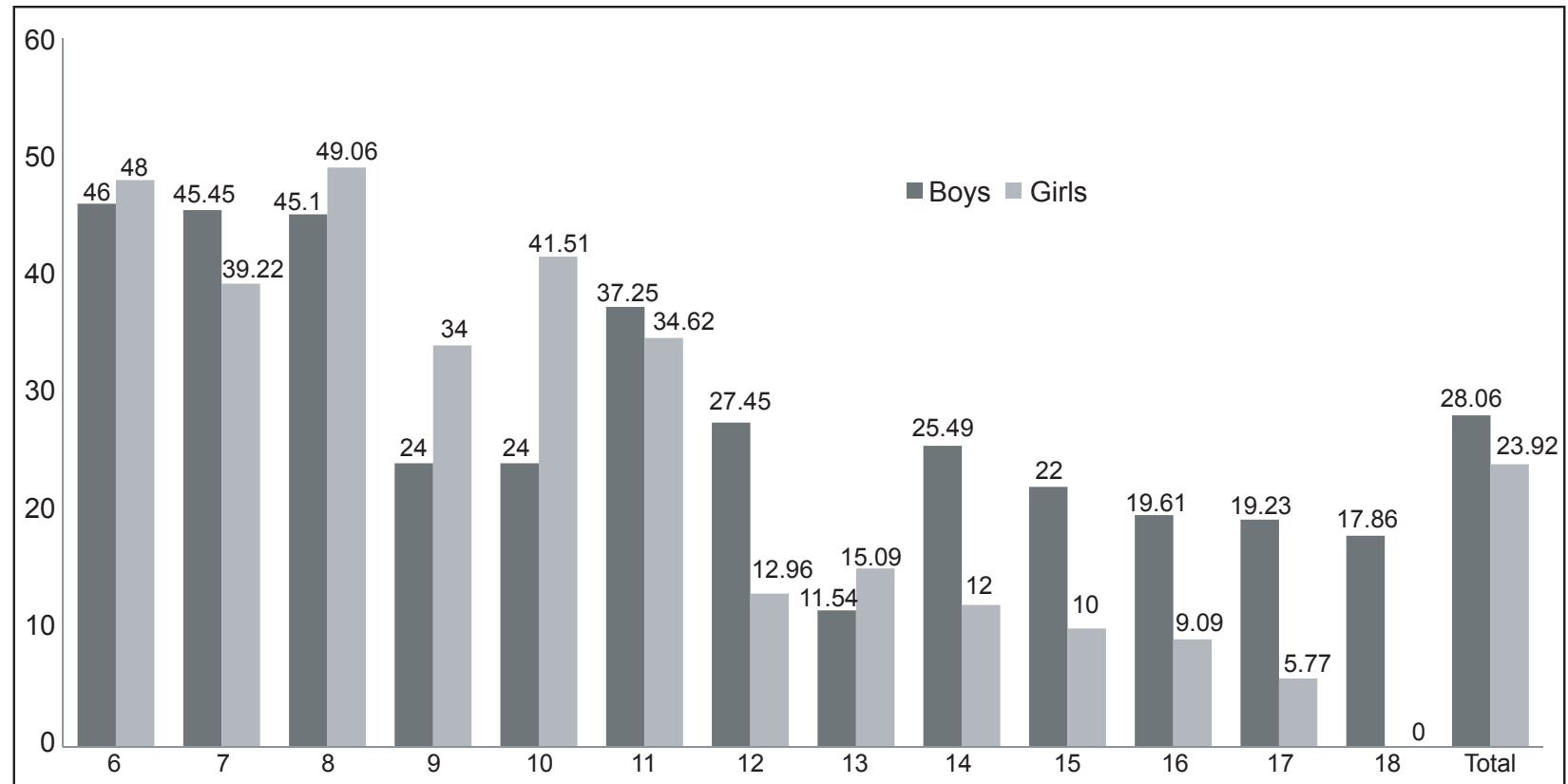

Fig 2: Age and sex specific prevalence of overall thinness (Grade I, II and III) among the Sonowal Kachari of Assam

Table 1: Age and Sex specific subject distribution, descriptive statistics (mean \pm SD) of weight, height, BMI and prevalence of thinness among Sonowal Kacharis of Assam, North-east India

\begin{tabular}{|c|c|c|c|c|c|c|c|c|c|c|c|c|c|c|c|c|c|}
\hline \multirow{3}{*}{$\begin{array}{c}\text { Age } \\
\text { (years) }\end{array}$} & \multirow{2}{*}{\multicolumn{2}{|c|}{$\begin{array}{c}\text { No of } \\
\text { Subjects }\end{array}$}} & \multirow{2}{*}{\multicolumn{2}{|c|}{ Weight (kg) }} & \multirow{2}{*}{\multicolumn{2}{|c|}{ Height $(\mathrm{cm})$}} & \multirow{2}{*}{\multicolumn{2}{|c|}{ BMI $\left(\mathbf{k g} / \mathbf{m}^{2}\right)$}} & \multicolumn{6}{|c|}{ Prevalence of Thinness } & \multirow{2}{*}{\multicolumn{3}{|c|}{$\begin{array}{c}\text { Sex difference } \\
\text { between } \\
\text { thinness } \\
\text { grades }\end{array}$}} \\
\hline & & & & & & & & & \multicolumn{2}{|c|}{ Grade III } & \multicolumn{2}{|c|}{ Grade II } & \multicolumn{2}{|c|}{ Grade I } & & & \\
\hline & Boys & Girls & Boys & Girls & Boys & Girls & Boys & Girls & Boys & Girls & Boys & Girls & Boys & Girls & $\begin{array}{c}x^{2} \\
\text { value }\end{array}$ & d.f. & p \\
\hline 6 & 50 & 50 & $\begin{array}{l}16.17 \\
\pm 1.46\end{array}$ & \begin{tabular}{|l|}
15.51 \\
\pm 1.70
\end{tabular} & \begin{tabular}{c|}
106.66 \\
\pm 3.87
\end{tabular} & $\begin{array}{c}105.96 \\
\pm 5.01\end{array}$ & $\begin{array}{l}14.21 \\
\pm 0.99\end{array}$ & $\begin{array}{l}13.79 \\
\pm 0.96\end{array}$ & $\begin{array}{c}2 \\
(4.00)\end{array}$ & $\begin{array}{c}2 \\
(4.00)\end{array}$ & $\begin{array}{c}4 \\
(8.00)\end{array}$ & $\begin{array}{c}8 \\
(16.00)\end{array}$ & $\begin{array}{c}17 \\
(34.00)\end{array}$ & $\begin{array}{c}14 \\
(28.00)\end{array}$ & 1.61 & 3 & 0.65 \\
\hline 7 & 55 & 51 & $\begin{array}{r}18.71 \\
\pm 1.97 \\
\end{array}$ & \begin{tabular}{|l|}
18.73 \\
\pm 2.08 \\
\end{tabular} & \begin{tabular}{|l|}
114.58 \\
\pm 4.74
\end{tabular} & \begin{tabular}{|l|}
113.78 \\
\pm 4.48
\end{tabular} & $\begin{array}{l}14.23 \\
\pm 0.98\end{array}$ & $\begin{array}{r}14.44 \\
\pm 1.08\end{array}$ & $\begin{array}{c}2 \\
(3.63)\end{array}$ & $\begin{array}{c}0 \\
(0.00)\end{array}$ & $\begin{array}{c}4 \\
(7.27)\end{array}$ & $\begin{array}{c}4 \\
(7.84)\end{array}$ & $\begin{array}{c}19 \\
(34.54)\end{array}$ & $\begin{array}{c}16 \\
(31.37)\end{array}$ & 1.88 & 3 & 0.60 \\
\hline 8 & 51 & 53 & $\begin{array}{l}20.67 \\
\pm 2.61\end{array}$ & \begin{tabular}{|l|}
20.19 \\
\pm 2.65
\end{tabular} & \begin{tabular}{|c|}
119.93 \\
\pm 5.47
\end{tabular} & $\begin{array}{c}119.86 \\
\pm 5.88\end{array}$ & $\begin{array}{l}14.32 \\
\pm 0.97\end{array}$ & $\begin{array}{l}14.01 \\
\pm 0.97\end{array}$ & $\begin{array}{c}0 \\
(0.00)\end{array}$ & $\begin{array}{c}1 \\
(1.89)\end{array}$ & $\begin{array}{c}5 \\
(9.80)\end{array}$ & $\begin{array}{c}10 \\
(18.86)\end{array}$ & $\begin{array}{c}18 \\
(35.29)\end{array}$ & $\begin{array}{c}15 \\
(28.30)\end{array}$ & 2.82 & 3 & 0.42 \\
\hline 9 & 50 & 50 & $\begin{array}{l}23.90 \\
\pm 3.04\end{array}$ & \begin{tabular}{|l|}
23.73 \\
\pm 3.68
\end{tabular} & \begin{tabular}{c|}
126.12 \\
\pm 6.26
\end{tabular} & \begin{tabular}{c|}
126.03 \\
\pm 6.63
\end{tabular} & $\begin{array}{l}14.97 \\
\pm 0.97\end{array}$ & $\begin{array}{r}14.85 \\
\pm 1.08\end{array}$ & $0(0.00)$ & $\begin{array}{c}0 \\
(0.00)\end{array}$ & $\begin{array}{c}2 \\
(4.00)\end{array}$ & $0(0.00)$ & $\begin{array}{c}10 \\
(20.00)\end{array}$ & $\begin{array}{c}17 \\
(34.00)\end{array}$ & 3.63 & 2 & 0.16 \\
\hline 10 & 50 & 53 & $\begin{array}{l}26.23 \\
\pm 3.32\end{array}$ & \begin{tabular}{|l|}
26.25 \\
\pm 3.14
\end{tabular} & \begin{tabular}{|c|}
131.32 \\
\pm 4.78
\end{tabular} & $\begin{array}{c}132.67 \\
\pm 5.28\end{array}$ & $\begin{array}{l}15.16 \\
\pm 1.17\end{array}$ & $\begin{array}{r}14.88 \\
\pm 1.19\end{array}$ & $\begin{array}{c}1 \\
(2.00)\end{array}$ & $\begin{array}{c}1 \\
(1.88)\end{array}$ & $\begin{array}{c}3 \\
(6.00)\end{array}$ & $\begin{array}{c}5 \\
(9.43)\end{array}$ & $\begin{array}{c}8 \\
(16.00)\end{array}$ & $\begin{array}{c}16 \\
(30.18)\end{array}$ & 2.04 & 3 & 0.56 \\
\hline 11 & 51 & 52 & $\begin{array}{l}29.94 \\
\pm 4.72\end{array}$ & \begin{tabular}{|l|}
31.74 \\
\pm 5.40
\end{tabular} & \begin{tabular}{|c|}
137.76 \\
\pm 8.17
\end{tabular} & $\begin{array}{c}139.83 \\
\pm 6.86\end{array}$ & $\begin{array}{r}15.70 \\
\pm 1.35\end{array}$ & $\begin{array}{r}16.15 \\
\pm 1.86\end{array}$ & $\begin{array}{c}1 \\
(1.96)\end{array}$ & $\begin{array}{c}0 \\
(0.00)\end{array}$ & $\begin{array}{c}1 \\
(1.96)\end{array}$ & $\begin{array}{c}2 \\
(3.84)\end{array}$ & $\begin{array}{c}17 \\
(33.33)\end{array}$ & $\begin{array}{c}16 \\
(30.76)\end{array}$ & 2.03 & 3 & 0.57 \\
\hline 12 & 51 & 54 & $\begin{array}{l}33.44 \\
\pm 5.54\end{array}$ & \begin{tabular}{|l|}
38.29 \\
\pm 5.77
\end{tabular} & \begin{tabular}{|c|}
143.28 \\
\pm 7.39
\end{tabular} & $\begin{array}{c}146.81 \\
\pm 6.22\end{array}$ & $\begin{array}{r}16.18 \\
\pm 1.39\end{array}$ & $\begin{array}{l}17.71 \\
\pm 2.00\end{array}$ & $0(0.00)$ & $\begin{array}{c}0 \\
(0.00)\end{array}$ & $\begin{array}{c}1 \\
(1.96)\end{array}$ & $0(0.00)$ & $\begin{array}{c}13 \\
(25.49)\end{array}$ & $\begin{array}{c}7 \\
(12.96)\end{array}$ & 2.76 & 2 & 0.25 \\
\hline 13 & 52 & 53 & $\begin{array}{l}38.89 \\
\pm 5.35\end{array}$ & \begin{tabular}{|l|}
42.42 \\
\pm 5.98
\end{tabular} & \begin{tabular}{c|}
150.49 \\
\pm 7.13
\end{tabular} & $\begin{array}{l}149.79 \\
\pm 5.35\end{array}$ & $\begin{array}{r}17.10 \\
\pm 1.23\end{array}$ & $\begin{array}{l}18.93 \\
\pm 2.71\end{array}$ & $0(0.00)$ & $\begin{array}{c}0 \\
(0.00)\end{array}$ & $\begin{array}{c}1 \\
(1.92)\end{array}$ & $\begin{array}{c}1 \\
(1.88)\end{array}$ & $\begin{array}{c}5 \\
(9.61)\end{array}$ & $\begin{array}{c}7 \\
(13.2)\end{array}$ & 0.27 & 2 & 0.87 \\
\hline 14 & 51 & 50 & $\begin{array}{r}45.83 \\
\pm 7.93\end{array}$ & \begin{tabular}{|l|}
44.23 \\
\pm 4.62
\end{tabular} & $\begin{array}{c}160.20 \\
\pm 8.69\end{array}$ & $\begin{array}{c}152.94 \\
\pm 4.56\end{array}$ & $\begin{array}{r}17.74 \\
\pm 1.86\end{array}$ & $\begin{array}{r}18.90 \\
\pm 1.69\end{array}$ & $0(0.00)$ & $\begin{array}{c}0 \\
(0.00)\end{array}$ & $\begin{array}{c}5 \\
(9.80)\end{array}$ & $\begin{array}{c}3 \\
(6.00)\end{array}$ & $\begin{array}{c}8 \\
(15.68)\end{array}$ & $\begin{array}{c}3 \\
(6.00)\end{array}$ & 2.26 & 2 & 0.32 \\
\hline 15 & 50 & 50 & $\begin{array}{l}48.53 \\
\pm 6.76\end{array}$ & \begin{tabular}{|l|}
45.40 \\
\pm 4.31
\end{tabular} & \begin{tabular}{c|}
162.23 \\
\pm 7.37
\end{tabular} & $\begin{array}{c}153.12 \\
\pm 3.58\end{array}$ & $\begin{array}{r}18.37 \\
\pm 1.69\end{array}$ & $\begin{array}{r}19.36 \\
\pm 1.65\end{array}$ & $0(0.00)$ & $\begin{array}{c}0 \\
(0.00)\end{array}$ & $\begin{array}{c}3 \\
(6.00)\end{array}$ & $0(0.00)$ & $\begin{array}{c}8 \\
(16.00)\end{array}$ & $\begin{array}{c}5 \\
(10.00)\end{array}$ & 3.39 & 2 & 0.18 \\
\hline 16 & 51 & 55 & $\begin{array}{l}50.35 \\
\pm 5.14\end{array}$ & \begin{tabular}{|l|}
46.88 \\
\pm 3.71
\end{tabular} & \begin{tabular}{|c|}
162.94 \\
\pm 5.38
\end{tabular} & \begin{tabular}{c|}
153.74 \\
\pm 5.09
\end{tabular} & $\begin{array}{r}18.95 \\
\pm 1.50\end{array}$ & $\begin{array}{r}19.84 \\
\pm 1.43\end{array}$ & $0(0.00)$ & $\begin{array}{c}1 \\
(1.81)\end{array}$ & $\begin{array}{c}1 \\
(1.96)\end{array}$ & $0(0.00)$ & $\begin{array}{c}9 \\
(17.64)\end{array}$ & $\begin{array}{c}4 \\
(7.27)\end{array}$ & 3.71 & 3 & 0.29 \\
\hline 17 & 52 & 52 & $\begin{array}{l}51.17 \\
\pm 3.62\end{array}$ & \begin{tabular}{|l|}
48.34 \\
\pm 4.45
\end{tabular} & $\begin{array}{c}163.41 \\
\pm 3.81\end{array}$ & $\begin{array}{c}154.39 \\
\pm 3.83\end{array}$ & $\begin{array}{r}19.16 \\
\pm 1.20\end{array}$ & $\begin{array}{l}20.27 \\
\pm 1.64\end{array}$ & $0(0.00)$ & $\begin{array}{c}0 \\
(0.00)\end{array}$ & $\begin{array}{c}1 \\
(1.92)\end{array}$ & $0(0.00)$ & $\begin{array}{c}9 \\
(17.3)\end{array}$ & $\begin{array}{c}3 \\
(5.76)\end{array}$ & 3.59 & 2 & 0.17 \\
\hline 18 & 56 & 50 & $\begin{array}{l}53.13 \\
\pm 4.81\end{array}$ & $\begin{array}{l}49.82 \\
\pm 3.95\end{array}$ & \begin{tabular}{c|}
164.06 \\
\pm 4.96
\end{tabular} & $\begin{array}{c}155.12 \\
\pm 4.61\end{array}$ & $\begin{array}{r}19.71 \\
\pm 1.21\end{array}$ & $\begin{array}{l}20.69 \\
\pm 1.04\end{array}$ & $0(0.00)$ & $\begin{array}{c}0 \\
(0.00)\end{array}$ & $\begin{array}{c}1 \\
(1.78)\end{array}$ & $0(0.00)$ & $\begin{array}{c}9 \\
(16.07)\end{array}$ & $0(0.00)$ & 8.29 & 2 & 0.01 \\
\hline Total & 670 & 673 & $\begin{array}{c}35.26 \\
\pm 13.86\end{array}$ & \begin{tabular}{|r|}
34.78 \\
\pm 12.66
\end{tabular} & \begin{tabular}{|l|}
138.88 \\
\pm 17.33
\end{tabular} & $\begin{array}{l}141.88 \\
\pm 20.74\end{array}$ & $\begin{array}{l}16.62 \\
\pm 2.34\end{array}$ & $\begin{array}{l}17.22 \\
\pm 2.93\end{array}$ & $\begin{array}{c}6 \\
(0.89)\end{array}$ & $\begin{array}{c}5 \\
(0.74)\end{array}$ & $\begin{array}{c}32 \\
(4.77)\end{array}$ & $\begin{array}{c}33 \\
(4.90)\end{array}$ & $\begin{array}{c}150 \\
(22.38)\end{array}$ & \begin{tabular}{|c|}
123 \\
$(18.27)$
\end{tabular} & 2.44 & 3 & 0.49 \\
\hline
\end{tabular}

Values in parenthesis indicate the percentages 
A high level of prevalence was observed in overall thinness is $25.99 \%$ ( $28.08 \%$ boys, $23.92 \%$ girls) Figure 2. The sex difference was found to be statistically insignificant using chi-square analysis $\left(x^{2}\right.$ value $=1.76$; d.f. $1 ; p>0.05)$. The overall prevalence in different thinness grades of mild (grade I; $22.38 \%$ vs. $18.27 \%$ ) and severe (grade III; $0.89 \%$ vs. $0.74 \%$ ) were found higher among boys than girls, with the exception in the moderate thinness category (grade II; $4.77 \%$ vs. $4.90 \%$ ) respectively. The prevalence of moderate (grade II) and severe (grade III) decreased with the advancement of age in both sexes, while no such trends observed in mild thinness (grade I) but the prevalence was found to be higher in early age groups. Age-specific overall thinness was found to be higher in 6 years $(46.00 \%)$ and 8 years (49.06\%), while lower incidences were observed in 13 years $(11.54 \%)$ and 17 years $(5.77 \%)$ among boys and girls respectively (Figure 2). The prevalence of thinness ranged from $1.96 \%$ (in 11 years) to $35.29 \%$ (in 8 years) and from $1.81 \%$ (in 16 years) to $34.00 \%$ (in 9 years) among the boys and girls, respectively. Using chisquare analysis, sex differences were found statistically insignificant $(p>0.05)$ in overall and respective ages specific prevalence of different grades of thinness, but only exception was found in 18 years $\left(x^{2}\right.$ value $=8$. 29; d.f. 2; p<0.05) Table I.

\section{Discussion}

The prevalence of undernutrition among children and adolescent are considered as a serious public health problem in developing countries such as India where the vast majority of the populations are undernourished and underprivileged ${ }^{1,12}$. It is well known that contemporary India consists of a sizable number of ethnic and indigenous elements having enormous amounts of ethnic and genetic diversity ${ }^{24}$. Such assessments are important for the improvement of their nutrition and health status, thereby overall development of the community concerned, where use of anthropometric measurements plays a pivotal role in the assessment of nutritional status ${ }^{11,12}$. In the present study the assessment of thinness among the children aged 6 years to 18 years belonging to the Sonowal Kachari tribal ethnic population of Assam, Northeast India was undertaken using newly proposed cut-off ${ }^{15}$. These new cut-off points were suggested to encourage direct comparison of trends in child and adolescent thinness worldwide and also provide a classification of thinness for public health purposes. Several studies have already reported the magnitude of thinness among Indian children and adolescents ${ }^{12,15-31}$ using these newly proposed international cut-off points ${ }^{15}$. Therefore, these cut-off values are valid for use among Indian children including these Sonowal Kachari children of Assam, Northeast India.
It is apparent from this study, that there is a high prevalence of overall thinness $(25.99 \%)$ observed among the Sonowal Kachari. The sex specific prevalence was found significantly higher among boys $(28.06 \%)$ than girls $(23.92 \%) \quad(p>0.05)$ Table I. The prevalence of thinness was significantly higher in the early age groups (e.g., 6-11 years), but decreased with the advancement of ages in both sexes. A similar trend has been reported by Mondal and Sen ${ }^{12}$ that the prevalence of thinness decreased with age among rural children of West Bengal, India. It has also been observed that several studies have reported that boys were more affected than girls in thinness among children and adolescents ${ }^{12,25,27,29,30}$. Several studies have reported very high prevalence of thinness of $62.26 \%$ in Bengalee $^{25}, 63.40 \%$ of rural children ${ }^{12}, 67.23 \%$ in KoreaModi $^{30}, 56.40 \%$ in Santal Tribe ${ }^{29}, 45.15 \%$ of Nepali children $^{31}$ than the present Sonowal Kachari (Table I). It is however now generally accepted that there is a high prevalence of thinness among Indian communities with more than $50.00 \%$ of children is being affected in higher aged groups ${ }^{32,33}$. It is evident from the above discussion, that the problem of thinness is persistent transversely among different Indian ethnic populations especially among the children and adolescents including these Sonowal Kachari with variable proportions residing in rural and tribal regions of India. The children suffering from thinness are more likely to develop into a thin adult individual with a low BMI (e.g., CED) that would have an impact on their work productivity as well as lead to greater prevalence of morbidity and mortality ${ }^{11,34}$. It can be summarized that the rural Sonowal Kachari under the present study is facing a greater risk in terms of undernourishment (e.g., thinness) which is even more pronounced among children of early ages. The poor nutritional status of the children, particularly girls in the higher ages, has important implications in terms of physical work capacity and adverse reproductive outcomes $^{11,35}$ and nutritional deficiencies, menstrual irregularity and eating disorders ${ }^{36,37}$.

\section{Conclusion}

Further studies should be conducted using the newly proposed thinness cut-offs for assessment of nutritional status of the different Indian population especially rural and tribal population for the nation and international comparison and development of new reference population for future comparison. The results of the present investigation will be useful for policy makers in their endeavour to formulate various developmental and health care programs. Nutritional intervention in terms of a comprehensive free supplements balanced diet and micronutrient rich or protective foods needs to be introduced to ameliorate the overall nutritional status and health condition. An effort should be made to disseminate the knowledge related to age specific 
nutritional requirements at the community level to warrant better quality of life among the children and adolescents.

Acknowledgement: The authors gratefully acknowledge the help and co-operation of the school and local village and block level authorities during the study. The extended help of Department of Anthropology, Dibrugarh University and all participants subject is also acknowledged. The financial assistance of the Indian Council of Social Science Research, New Delhi (ICSSRref. No. F.No. 5-38/Cont/07/Fel) is also acknowledged.

Funding: This study was done with partial financial assistance in the form of Ph.D contingency grant of the Indian Council of Social Science Research, New Delhi (ICSSR- ref. No. F.No. 5 38/Cont/07/Fel).

Conflict of Interest: Nil.

\section{References}

1. Nandy S, Irving $M$, Gordon D, Subramanian SV, Smith GD. Poverty, child undernutrition and morbidity: New evidence from India. Bull World Health Org 2005;83:210-216.

2. Zere E, Mclntyre D. Inequities in under-five child malnutrition in South Africa. Int $J$ Equity Health 2003;2:7.

3. Black RE, Allen LH, Bhutta ZA, Caulfield LE, de Onis M, Ezzati M, Mathers C, Rivera J. Maternal and child undernutrition: Global and regional exposures and health consequences. Lancet 2008;371:243260.

4. Save the Children. A Life free from hunger- Tackling child malnutrition. Save the Children, London, 2012.

5. Khor GL. Food-based approaches to combat the double burden among the poor: Challenges in the Asian context. Asia Pac J Clin Nutr 2008;17:S111S115.

6. Bamji MS. Early nutrition and health - Indian perspective. Curr Sci 2003; 85:1137-1142.

7. Measham AR, Chatterjee M. Wasting away: The crisis of malnutrition in India. The World Bank: Washington DC, 1999.

8. The HUNGAMA Survey Report. 2011. Fighting Hunger \& Malnutrition. Available from http://www. hungamaforchange.org/HungamaBKDec11LR.pdf [Assessed October 12, 2012].

9. Pelletier DL. Malnutrition, morbidity and child mortality in developing countries: In: editors. Too young to die: Genes and gender? ST/ESA/ SER.A/155. New York: United Nations, Department of Economics and Social Affairs, Population Division, 1998: 109-132.
10. Griffiths PL, Bentley ME. The nutrition transition is underway in India. J Nutr 2001;131:2692-700.

11. World Health Organization. Physical status: the use and interpretation of anthropometry. Technical Report Series No. 854. Geneva: World Health Organization, 1995.

12. Mondal N, Sen J. Prevalence of under-nutrition among children (5-12 years) belonging to three communities residing in a similar habitat in North Bengal, India. Ann Hum Biol 2010; 37:199-217.

13. Sen J, Mondal N. Socio-economic and demographic factors affecting the Composite Index of Anthropometric Failure (CIAF). Ann Hum Biol 2012;39:129-36.

14. Cole TJ, Bellizzi MC, Flegal KM, Dietz WH. Establishing a standard definition for child overweight and obesity worldwide: international survey. BMJ 2000;320:1240-3.

15. Cole TJ, Flegal KM, Nicholls D, Jackson AA. Body mass index cut offs to define thinness in children and adoles-cents: international survey. BMJ 2007;335:194.

16. Government of Assam. Statistical Hand Book of Assam, Directorate of Economics and Statistics. Government of Assam, Guwahati: Assam, 2006.

17. Sengupta S: Kachari Sonowal: In K. S. Singh, editor. People of India: Assam.Vol. XV Part one. Calcutta: Seagull Books, 2003: 352-8.

18. Singh K.S. The Scheduled Tribes, People of India: National Series. Volume III, Calcutta: Oxford University Press, 2012.

19. Touitou Y, Portaluppi F, Smolensky MH, Rensing L. Ethical principles and standards for the conduct of human and animal biological rhythm research. Chronobiol Int 2004;21:161-170.

20. Weiner, JS, Lourie, JA. 1981. Practical human biology. London: Academic Press, 1981.

21. Ulijaszek SJ, Kerr DA. Anthropometric measurement error and the assessment of nutritional status. $\mathrm{Br} \mathrm{J}$ Nutr 1999;82:165-77.

22. Cole TJ, Green PJ. Smoothing reference centile curves: the LMS method and penalizedlikelihood. Statistics in Medicine 1992;11:1305-19.

23. Cole TJ, Freeman JV, Preece MA. British 1990 growth reference centiles for weight, height, body mass index and head circumference fitted by maximum penalized likelihood. Statistics in Med 1998;17:407-29.

24. Indian Genome Variation Consortium. Genetic landscape of the people of India: a canvas for disease gene exploration. J Genet 2008;87:3-20. 
25. Chakraborty R, Bose K. Very high prevalence of thinness using new international body mass index cut off points among 5-10 year old school children of Nandigram, West Bengal, India. J Res Med Sci 2009;14:129-33.

26. Biswas S, Bose K, Bisai S, Chakraborty R. Prevalence of Thinness among Rural Bengalee Pre-school Children in Chapra, Nadia District, West Bengal, India. Mal J Nutr 2009;15:155-164.

27. Bisai S, Manna I. 2010. Prevalence of Thinness among urban poor pre-School children in West Bengal, India. Sudanese J Pub Health 2010;5:19398.

28. Mondal N, Jaydip S. Thinness is a major underlying problem in Indian children. $J$ Trop Pedtr 2010;56:456-8.

29. Das S, Bose K. Prevalence of thinness using new international cut-off points among Santal tribal children and adolescents of Purulia District, West Bengal, India. Sri Lanka J Child Health 2011;40:105110

30. Bisai S, Ghosh T, De GK, Bose K. Very High Prevalence of Thinness among Kora-Mudi Tribal Children of Paschim Medinipur District of West Bengal, India. EJBS 2010; 43-49. http://www.ejarr. com/volumes/vol3/ejbs_3_06.pdf
31. Das S, Banik SD. Prevalence of thinness among Nepali speaking preschool children of Darjeeling using Body Mass Index cut-off points. Italian J Pub Health 2011;8:241-46

32. de Onis M, Dasgupta $P$, Saha, S, Sengupta D, Blossner, M. The National Center for Health Statistics reference and the growth of Indian adolescent boys. Am J Clin Nutr 2001;74:248-53.

33. Deshmukh PR, Gupta SS, Bharambe MS, Dongre AR, Maliye C, Kaur S, et al. Nutritional status of adolescents in rural Wardha. Indian $J$ Pediatr 2006;73:139-41.

34. Strickland SS. Functional consequences of adult malnutrition in developing countries: a review. J Physiol Anthropol 2002;21:1-9.

35. Rao S. Nutritional status of the Indian population. $J$ Biosci 2001;26:481-489.

36. Turner JM, Bulsara MK, McDermott BM, Byrne GC, Prince RL, Forbes DA. Predictors of low bone density in young adolescent females with anorexia nervosa and other dieting disorders. Int J Eat Disord 2001;30:245-51.

37. Misra M, Aggarwal A, Miller KK, et al. Effects of anorexia nervosa on clinical, hematologic, biochemical, and bone density parameters in community-dwelling adolescent girls. Pediatrics 2004;114:1574-83. 